\title{
Enhancing Sustainable Tourism through Proper Solid Waste Management
}

\author{
Wylyn Lance 0. Todyog, John Edward M. Alvarado
}

University of the Cordilleras, Baguio City, The Philippines

Email: fpino785@gmail.com

How to cite this paper: Todyog, W. L. O., \& Alvarado, J. E. M. (2021). Enhancing Sustainable Tourism through Proper Solid Waste Management. Open Journal of Social Sciences, 9, 255-260. https://doi.org/10.4236/jss.2021.93017

Received: August 27, 2020

Accepted: March 19, 2021

Published: March 22, 2021

Copyright $\odot 2021$ by author(s) and Scientific Research Publishing Inc. This work is licensed under the Creative Commons Attribution International License (CC BY 4.0).

http://creativecommons.org/licenses/by/4.0/ (c) (i) Open Access

\begin{abstract}
Sustainable tourism is one of the aspects that contributed to the growing economy of Baguio City wherein the place itself is the avenue of income for the city. Baguio City is a landlocked mountainous town located in the northern region of the Philippines. It is particularly known as the "Summer Capital of the Philippines" due to its colder temperature during summer season. One of the famous landmarks in the city is Burnham Park where it is annually visited by many guests, either local or foreign tourists. Because of the frequent arrival of people in the city, increasing hike of garbage collection within the area of Burnham Park and its nearby vicinity is often observable. The study aims to propose a way on how to address the increasing garbage collection for the betterment and promotion of the sustainable tourism of Burnham Park. The study used a variety of tools in conducting the research primarily oral and recorded interview regarding the solid waste management primarily the immediate personnel designated in the park and people visiting Burnham Park and an ocular observation of the park for the establishment of collected data. Data were analyzed through relating the data in literatures and news journals to reinforce the collected data. The study showed main ways on how to enhance the sustainable tourism of Burnham Park like the distribution of garbage bins that could suffice the needs of tourists and locals and the strict implementation of policies regarding cleanliness in Burnham Park. The researchers concluded that proper solid waste management will be successful through the cooperation of locals and tourists and with the strict implementation and compliance of policies regarding waste disposal in Burnham Park. Proper waste management in Burnham Park will not only improve the cleanliness of the park thus promoting the culture of cleanliness and tourism of Baguio City.
\end{abstract}

\section{Keywords}

Solid Waste Management, Sustainable Tourism, Ordinance, Practical 
Solutions, Seasonal Events

\section{Introduction}

"The greatest threat to our planet is the belief that someone else will save it." (Swan, 2014)

Tourism is one of the avenues that the government uses to promote its country and to generate income. Because of this, its citizen has an obligation to preserve and maintain the environment they belonged to.

Sustainable tourism development requires the participation of all stakeholders, as well as strong social leadership to ensure participation and cooperation. Achieving sustainable tourism is a continuous process and it requires constant monitoring of impacts, introducing the necessary preventive and/or corrective measures whenever necessary (World Tourism Organization, 2004). According to the World Tourism Organization, sustainable tourism is "Tourism that takes full account of its current and future economic, social and environmental impacts, addressing the needs of visitors, the industry, the environment, and host communities". Sustainable tourism supports the local economy and community tourism by purchasing local products, helping and supporting the community and ensuring the financial benefits of people there. This solves the social problems that result from a lack of employment and helps to establish local people of their livelihoods. The key to a thriving tourism industry is addressing how tourism can benefit a community by developing economic opportunities, supporting socio-cultural policies and the maintenance of a healthy ecosystem on which communities depend.

One of the ways to maintain a healthy ecosystem is through proper solid waste management. Wastes can potentially overload waste management systems, especially in destinations that are more rural in nature or have a low population. This increase is quite often seasonal as many cities have peak seasons in either winter or summer. Because of the influx of tourist, the local government cannot immediately monitor the arrival and movements of tourists, both local and foreign. Overloading, as well as tourists' lack of familiarity with differing waste systems, can lead to improper waste disposal, which can in turn lead to environmental problems such as groundwater or soil contamination and greenhouse gas emissions, among others (World Tourism Organization, 2014). Some of the basic solutions to address such concerns are providing of standardized designated garbage areas within the vicinity of the park and a stricter implementation of regulations regarding waste disposal in the park which will be propagated by the designated officers within the park. And lastly, all of these will be achieved through the cooperation of all the people visiting Burnham Park, whether they are local or foreign tourists and also with the help of people residing there.

Parks are more than just parks today. Green, open space must do double, triple 
and even quadruple duty. They must be "the traditional park", but they're also cultural institutions, botanical gardens and providers of social services (Hammond et al., 2017). Parks provide a great benefit to citizens, both local tourists. In addition to their many environmental benefits, parks create an economic benefit for both governments and individuals. Creating a well-planned park and preserving enough land for them can generate financial returns, even when maintenance costs are factored in. The researchers aimed to address the need of the different parks in Baguio City especially Burnham Park of having and maintaining a proper solid waste management.

The city and its residents learned the bad effects of improper waste management. It is a good thing that the locals learned from the previous mistakes and taken early measures and implemented different ordinances adrresing the issues about solid waste management. Councilor Lilia A. Fariñas, one of the councilors in Baguio City, authored and proposed an ordinance embracing the Bigay Dangal sa Kabuhayan (BIDAKA) program as a means of livelihood for residents as one of the alternative and practical solutions to the solid waste management problems of the city (See, 2020). BIDAKA focused on the recycling and reusing of garbage materials like plastics to useful products like schoolbags, money bags, seminar or conference bags, and the other products. It also includes and encourages out of school youths and all the barangays to active participating in the said endeavor. In this ordinance, it effectively and efficiently addresses the present environmental objectives of the local government.

\section{Statement of the Problem}

As such, the researchers will be guided with the following main objectives which will be reinforced by the specific objectives:

Main Objectives:

1) How can sustainable tourism help in the development of the city's cleanliness especially in parks?

2) What are the ways to promote and implement proper solid waste management in parks?

Specific Objectives:

1) What are the challenges faced by Burnham Park in terms of tourism and cleanliness?

2) How should the tourists and the local government address such challenges?

\section{Methodology}

The research focused on the promotion of local tourism of Baguio City specifically Burnham Park through the implementation of proper solid waste management. Baguio City is known for its strict implementation and compliance regarding cleanliness but there are some lapses of these regulations especially during seasonal events in the city. In this, the researchers conducted an oral and written interview to the staffs of Burnham park to gather the necessary data and 
information needed for the research, with these there were only 10 available staffs to conduct the research. Data was studied and tested through thematic analysis in which data was examined and identified common topics, ideas, and patterns of meaning from a set of written and interview transcripts. In relation to this, identities of respondents were of discretion to protect their privacy. Interviews conducted were of consent by the respondents before it was initiated.

The questions asked in the interview conducted are the following:

1) How many years have you been a staff/worker here?

2) With your experience how did you regulate the trash during peak seasons? What are your suggestions to still maintain the cleanliness?

3) What do you think are the reasons tourist come here in Baguio? What are your suggestions to maintain the rate of tourists coming in?

\section{Discussion}

Baguio City is famed for its tourism, accommodating residents and suited temperature enjoyed by local and foreign tourists. Burnham Park is one of the tourist spots offered by the city. It greatly attracts tourists because of its aesthetic sceneries, grandiose landscaping and accommodating people serving different tourists. Like other places, Burnham Park is facing different problems and challenges encountered by different people visiting the park.

In an interview, the researchers found out different challenges faced by the park. First, local maintaining officers in the park considered the lack of discipline of tourists, both local and foreign, as the main contributor to the problems of the park. Based on the interview by ten maintaining officers, tourists often dispose their trash on places they were situated in like benches and grass areas. According to maintaining officers, tourists lacked initiative in disposing their garbage in proper garbage areas were often done during peak seasons in the park. Second, local maintaining officers believed that the local government should have stricter implementation of park policies and more observable interventions in the park. For example, according to Administrative Order 21, series of 2015; Rules and Regulations governing operation and maintenance of the "Burnham Park Reservation", or known as the anti-smoking, peddling and intake of intoxicating liquor in the park, and public scandal involving minors. Violators for these were to pay (Fianza, 2020). The lack of manpower implementing policies is on the things local maintaining officers pointed out. In an interview, the park was guarded by 14 to 15 security guards but recently only 7 were assigned in the park according to maintaining officers. On the other hand, local maintaining officers believed that Burnham Park should be provided with more garbage bins and should have proper and designated disposing areas.

According to one of the maintaining officers, sustaining the rate or the population of the tourist especially peak seasons, many of them such as sweepers and guards are patrolling throughout the day to ensure the safety of the park and the tourists. To reduce the garbage problem, they themselves are the one recycling 
this, that's why they need man power, they need more employees such themselves to ensure that this garbage's could not be a hindrance to the developing success of Burnham Park. Not just maintaining the cleanliness but also the beautification of the park, the park must stand out for its name, that is why installing fountains to attract tourists is one way and planting more flowers to enhance and to stand out.

In maintaining sustainable tourism of Burnham Park, the government and tourists would work hand in hand in maintaining the beauty and cleanliness of the park. Local government would provide more manpower in implementing park policies and to provide sufficient garbage bins catering to the number of tourists visiting the park. People visiting the park should have the initiative disposing their trash properly in designated garbage areas. In these, every tourists, local and foreign, will enjoy their visit and stay in the famed Burnham Park.

\section{Conclusion and Recommendation}

Through the study, the researchers conclude that with proper cooperation and communication of the local government with the people of Baguio, this will ensure the strict compliance of the policies and regulations within the city.

To the local government, we recommend providing more uniformed men around the park for the safety of the people especially to children. Also, we recommend providing more employees maintaining the beauty of the park.

To the people of Baguio and the local tourists, we recommend to strictly follow the rules being implemented by the local government for the security and safety of everybody.

\section{Acknowledgements}

The manuscript team would like to thank Dr. R.A. and Dr. T.D.P., of the University of the Cordilleras, as well as the undying support of other researchers.

\section{Conflicts of Interest}

The authors declare no conflicts of interest regarding the publication of this paper.

\section{References}

Fianza, J. (2020). Burnham Park Report. https://www.baguio.gov.ph/content/burnham-park-report

Hammond, R. et al. (2017). The New Definition of the Community Park. https://realtytimes.com/consumeradvice/homeownersadvice/item/1005708-20171003-t he-new-definition-of-the-community-park

See, D. (2020). Solution to City's Solid Waste Problem Sough. https://baguio.gov.ph/content/solution-city\%E2\%80\%99s-solid-waste-problem-sough

Swan, R. (2014). Robert Swan-Stories from beyond Two Poles.

https://www.ecologic.eu/11745

World Tourism Organization (2004). Sustaining Tourism. 
https://sustainabletourism.net/sustainable-tourism/definitions/

World Tourism Organization (2014). Defining Sustainable Tourism. https://www.gdrc.org/uem/eco-tour/sustour-define.html 